Yang, Hongzhi and Clarke, Matthew

ORCID: https://orcid.org/0000-0003-4693-248X (2018) Spaces of agency within contextual constraints: A case study of teachers' response to EFL reform in a Chinese university. Asia-Pacific Journal of Education.

Downloaded from: http://ray.yorksj.ac.uk/id/eprint/2754/

The version presented here may differ from the published version or version of record. If you intend to cite from the work you are advised to consult the publisher's version: https://www.tandfonline.com/doi/full/10.1080/02188791.2018.1460252

Research at York St John (RaY) is an institutional repository. It supports the principles of open access by making the research outputs of the University available in digital form. Copyright of the items stored in RaY reside with the authors and/or other copyright owners. Users may access full text items free of charge, and may download a copy for private study or non-commercial research. For further reuse terms, see licence terms governing individual outputs. Institutional Repository Policy Statement

\title{
RaY
}

Research at the University of York St John

For more information please contact RaY at ray@yorksj.ac.uk 


\section{Spaces of agency within contextual constraints: A case study of teachers' responses to EFL reform in a Chinese university Introduction}

Since the end of the last century, the Chinese government has initiated the Higher Education Quality and Reform Project (HEQRP) (CMoE, 2002), which has had a significant impact on teachers' practice (Lo, Lai, \& Wang, 2013). To successfully implement the reforms, teachers not only need to apply the new curricula in their classroom practice, but also change their beliefs and commitment accordingly (Yin, 2012). However, the complexity of the classroom has often been ignored by the policy makers, who expect teachers to implement reform as if this was as simple and straightforward as changing one's uniform (S. J. Ball, 2012; S J Ball, Maguire, \& Braun, 2012). In particular, policy makers often overlook the role of teachers as active agents in the process of educational reform. Therefore, it is necessary to research teachers as agentive actors during educational reforms and to analyse the reasons underlying successful or unsuccessful implementation, thus providing additional insights into the processes of curriculum reform implementation (Day \& Gu, 2013; Hargreaves, 2003).

The context of this study is the educational reform of English as a Foreign Language (EFL) for non-English major students in the Chinese tertiary level, known as 'College English'. In the Chinese context, a growing sense of crisis in relation to the existing curriculum, which embodies an examination-driven education model, has driven reform of the College English curriculum. Reflecting this sense of crisis, significant reform was initiated by the Chinese Ministry of Education (CMoE) in 2007. The reform requires teachers to teach students using a wider variety of reading strategies, incorporating a focus on both top-down global understanding and bottom-up word decoding strategies (CMoE, 2007). However, a number of deeply entrenched ideas, practices, and structures exist that are in conflict with the thrust of the reforms (Zhong, 2006). Internationally, the last twenty years has witnessed a wide range of research on English language teachers, from research studies on teacher skills, teacher thinking, teacher knowledge, teacher reflection, teacher autonomy and teachers-as-researchers (Andrews, 2007; Hong \& Youngs, 2014; Sato, 2003). Against this background, it is important to explore the experiences of Chinese teachers who are working in a distinctive historical, political and cultural context and who are experiencing considerable pressure to change (Gu, 2013). While some of their experiences may 
also have similarities with those of their Western counterparts', there are also differences related to historical and contextual features. In China, very few studies to date have explored the views of Chinese university teachers and their professional practice (Wette \& Barkhuizen, 2009), with most literature focused on secondary schools and relatively little research addressing educational reform in higher education ( $\mathrm{Li}, 2011)$. Therefore, this exploratory study will investigate teacher pedagogical agency in implementing College English curriculum reform in the wider Chinese context.

\section{Theoretical framework}

Among studies of educational reform, few elucidate how teachers' agency and actions might be theorized in relation to reform as it unfolds at different 'scales' or 'levels', from government policy makers to institutional managers to the world of the classroom. To address this gap, the current paper explores the policy enactment of the latest College English reform in China and the interaction between national policies, institutional policy and teacher agency in responding to this educational reform. It does so from the perspective of activity theory (Engeström, 1987), thereby linking the individual with the social structure to highlight the relational construction of agency through the use of artefacts and tools (Engeström \& Miettinen, 1999; Johnson \& Golombek, 2011). More specifically, activity theory offers the prospect of illuminating how government reform policy creates new tools and expectations for teaching, thus potentially providing insights into how teachers perceive and have interaction with new reform mandates (Lasky, 2005).

Activity theory involves analysis of the interactions between a numbers of components of an 'activity system'. In 'first generation' activity theory (Leont'ev, 1981), this system comprised subjects, objects, and the tools mediating between them represented, respectively, by the left-hand, right-hand and upper points of the triangle. However, criticism of the decontextualized nature of such analyses led to the development of 'second generation' activity theory, which incorporated further elements, including 'rules', 'community', and 'division of labour'. These additional elements are represented in the lower level of the activity system diagram. 'Third generation' activity theory extends the analytic reach of this more complex model yet further by enabling the analysis of the interaction between two or more related 
activity systems (Engeström, 2009), whilst also making it possible to depict and analyse the hierarchical power relationship (Blackler \& McDonald, 2000). Figure 1, below, depicts the minimal model of third generation activity theory, involving at least two interacting activity systems.

van Huizen, van Oers, and Wubbels (2005) suggest three levels for the activity system of teaching: a macro-level, in which the societal values and priorities reflected in education policy frame curriculum, pedagogy and assessment practices; a meso-level, in which institutions are positioned within the boundaries of the given macro-frames and; a micro level, where the meaning of teaching is negotiated in interactive situations such as classrooms, conference seminars, or collegial consultations, against the background of the macro-societal and meso-institutional levels. In this study, the implementation of educational reform is conceptualised as a joint-activity system between three activity systems comprising: the $\mathrm{CMoE}$ as the macro-level policy initiator; the university as a meso-level policy translator and implementer and; an individual teacher's classroom practice as a micro-level space of policy enactment and potential agency. In order to illuminate the issues framing, enabling and constraining this teacher agency, the analysis focuses on the hierarchical power relationships and the distribution of management rules, as well as the potential shared objects between the three related activity systems involved in the educational reform. Critically, the interplay between these activity systems, as well as that within the components of one activity system, is considered simultaneously in order to reveal either the synergies or the contradictions within the activity system. These contradictions are believed to have the possibility to generate transformation if they can be resolved (Engeström, 2001). Hence, our analysis examines the tensions and contradictions within and between the three activity systems at each level, as well as examining the power distribution between these three activity systems in order to illuminate teachers' contextually constrained agency in the face of attempts to reform English language education in Chinese universities.

\section{Methodology}

This study is located within a social constructionist epistemology and adopts a case study approach while employing activity theory. Data was generated via a number of strategies, including classroom observation, interviews with the teacher, her students 
and the Head of the College English Department and examination of reform policy documents.

The participant teacher's classroom practice was observed and videotaped for 18 hours over two months. During this period, six students from the participant teacher's class were invited to participate in a one-hour focus group interview. The students were selected mainly according to their English proficiency levels, including two students from a high level, two from a medium level, and two from a lower level. At the end of classroom observation, semi-structured interviews were conducted with the teacher about their beliefs about teaching and their agency to change the teaching. In addition, a short semi-structured interview was conducted with the Head of the Department, Daniel (pseudonym), whose responsibilities included organizing and evaluating teaching, as well as chairing a regular weekly meeting for the teachers who taught the course New Horizon College English. The interview aimed to explore his beliefs about teaching and management, as well as probing his understanding about the curriculum reform. Appropriate institutional ethical approval was granted for this research and participants provided informed consent, while pseudonyms have been employed throughout.

Data analysis drew on the conceptual framework of activity theory (Engeström, 2009) and focused on identifying contradictions within and between the three levels to identify and examine potential spaces for agency against a background of contextual constraints in the form of hierarchical power relationships. More specifically, the paper uses Critical Discourse Analysis (CDA) to analyse the transcribed observation and interview data and the institutional and government policy texts, so as to explore individual teacher agency in the context of educational reform in China when viewed through the lens of third generation activity theory.

In this study, the policy documents and interview transcripts were analysed in relation to text structure, grammatical features, such as the use of modal operators, mood and transitivity, and lexical choices to foreground the ideology and power relationship created by the discursive practice of reform implementation (Fairclough, 2001). Modality is particularly significant in highlighting issues of power and ideology. In CDA, modality refers to the speaker or writer's degree of commitment to certainty, necessity or obligation (Halliday, 1994; Lilian, 2008). Modality is expressed in a range of linguistic forms, such as modal auxiliary verbs (may, shall, must, need etc.), 
sentence adverbs (probably, certainly etc.), nominalizations (obligation, desirability, authority), and some verbs (permit, prove, allow) (Fowler, 1985). Similar to the modality in English, in Chinese, a speaker's attitude is expressed through the use of modal adverbs. These may be placed at the beginning of a sentence or between the subject and the predicate, for example, 大概 da gai 'presumably', 肯定 kending 'definitely', 一定 yiding 'certainly'; and, the preceding modal verb or modal adjective, for example, 必須 bixu 'must', 應該 yinggai 'should', 要 yao 'must' and so on (Cheng, 2016). These model expressions not only indicate the speaker's attitude but are also used by the speaker to influence the audience's attitude and behaviour (Cheng, 2016).

\section{Macro context - the Chinese Ministry of Education}

The Chinese Ministry of Education (CMoE) of the People's Republic of China, which can be viewed as the subject of the macro-level activity system, assumes the role of initiating, planning, implementing and monitoring educational reform. In 2004 and 2007, the CMoE authorized a committee of experts to design the College English Curriculum Requirements (CECR) (based on an initial pilot) in order to initiate the educational reform. The goal of reform represents the object of the system. In addition, the $\mathrm{CMoE}$ also issued a wide range of policies in order to implement the reform, such as the College English Curriculum Requirements (CECR). Those policy documents can be regarded as the tools in relation to the implementation of the reform. As for the division of labour, all decisions are made by the national government and imposed in a top-down manner on the lower levels of the educational system $(\mathrm{CMoE}$, 2003, 2004b), while the role of Higher Education Institutions (HEIs) is just to implement the policies initiated by the government and collect data to report back to the state or provincial government, reflecting the compliant and bureaucratic culture of educational reform in China (Qian \& Verhoeven, 2004). This section analyses the structure, grammatical feature and vocabulary use in the reform policies.

The CECR was structured into six sections: Character and Objectives of College English; Teaching Requirements, including basic, intermediate, and higher requirements; Course Design; Teaching Model; Evaluation; Teaching Administration. The whole document is prescriptive in relation to students, teachers and education 
administrators reflected in the frequent use of imperative sentences. For instance, in Section IV, the requirements for Teaching Model:

Colleges and universities should remould the existing unitary teacher-centered pattern of language teaching by introducing computer- and classroom-based teaching models.

Driving the CMoE's reform agenda is the belief that education must serve the nation and society's needs (Li, 2011). This is evident in the following excerpt from the 2007 report:

In order to fully implement the reform of college English teaching and meet the needs of the national and social training in the new period, we will organize the relevant experts to revise and improve the requirements of college English teaching reform, combined with the practice of college English teaching reform. The revised "College English Course Teaching Requirements" is now issued to you as the reference for the implementation. (CMoE, 2007).

Similarly, in the first paragraph of the College English Curriculum Requirements (CECR), the reform is justified in similar terms:

In order to meet the new situation of higher education development in our country, deepen the reform of teaching, improve the quality of teaching and meet the needs of the country and society in the new period, we have formulated the "College English Course Teaching Requirements" (hereinafter referred to as "Course Requirements").

Yet the $\mathrm{CMoE}$ is not oblivious to the differing circumstances and varying needs of the institutions it is seeking to reform. As the introduction to the CECR explicitly states:

Taking into account the school's circumstances, colleges and universities should follow the guidelines of the Requirements and the goals of their College English teaching in designing their College English course system.

As this suggests, the $\mathrm{CMoE}$ was aware of the regional differences of the EFL teaching in China and allowed local institutes to create their own syllabus based on their contextual situation. However, the authoritative role of the national curriculum requirements in the process of reform should not be underestimated. The Notice of Implementing the Pilot Projects of the College English Curriculum Reform (CMoE, 2004b) states: 
College English teaching reform is an important part of teaching quality and teaching reform in colleges and universities. The educational administrative departments and tertiary institutes in different provinces should further update their educational concepts and raise their awareness of the importance of college English teaching reform. The province (including autonomous regions and municipalities) and the tertiary institutions should have unified deployment, and strengthen the leadership of this work to take this reform as a work to improve the quality of personnel training (CMoE, 2004b).

In these policy documents, the use of managerial terminology, such as 'unified deployment', 'strengthen the leadership', underscores the authoritative position assumed by the $\mathrm{CMoE}$ in implementing the reform by imposing their concepts on the education section at the provincial level. This authoritative positioning is re-enforced at the level of tenor through the use the inclusive first-person plural, 'we' to refer to themselves in stark contrast to the use of the more distant third person 'their' in relation to the education institutions at the provincial level. In addition, the use of the modal auxiliary 'should' indicates the CMoE's assumed power in enforcing the ideology of conformity. The reform policy documents are a kind of tools, as well as rules, intended to ensure compliance from higher education institutions in implementing the reform. The repeated deployment of the word 'training' also suggests the top-down style of implementation, reflecting an assumption of deficiency in relation to the institutes and teachers who need to be instructed to meet the requirements and who are given little if any credit for agency or initiative.

Importantly, the reform policy specifies requirements in relation to classroom pedagogical practice. For instance, in relation to reading instruction, the CECR brings a new 'conceptual' focus, stating that students are required to understand the main ideas and supporting details and to use of a range of reading strategies while reading. However, the dominant approach to reading pedagogy in EFL teaching in China focuses on 'mechanical' aspects such as lexical decoding, grammar exercises and translation. Therefore, according to the reform requirements, teachers need to shift their teaching practice from grammar-translation approach to a far more interactive and varied approach to teaching reading, which focuses on conceptual understanding of ideas. 
The vocabulary choice in the curriculum requirement suggests the role of teachers as constructed by the policy. Table 1 summaries the key verbs including modal verbs used in the CECR. The choice of lexical fields from a managerial discourse (e.g. assess, manage) suggests a view of teaching as a technical activity, which can be inspected, evaluated and measured. In addition, the curriculum objectives, such as "the objective of College English is to develop students' ability to use English in a well-rounded way" and the repetitive use of the phrase "they should be able to", suggests an outcomes-based approach, in which teachers deploy a toolkit of strategies in order to achieve the teaching objectives - an approach which has been described as a form of Taylorism in education (Au, 2011; Stoller, 2015). Meanwhile, the use of relatively strong degree of modality (e.g. should/is to) creates a powerful sense of obligation for teachers, reflecting the view of teaching as a mechanical process of implementation rather than a dialogic or developmental professional practice.

In these ways, the universities were cast in a passive position, whereby they had to adopt the teaching approach prescribed by the policy makers. Unsurprisingly, the consequence of the technical emphasis on equipping teachers with skills and knowledge, rather than developing local capacities to take professional ownership of transformation, is superficial compliance at the university and classroom level.

\section{Meso context - the periphery university}

In China, there are different ways of categorising universities. The official categorisation includes 112 'key universities' and the rest comprising those not deemed to be 'key'. (According to the 2017 statistics, there are 2366 state-run institutes and 265 private/independent ones (CMoE, 2017). The research setting of this study was University ZS located in Henan province, one of the economically disadvantaged provinces in Central China. The university where data were collected is a joint venture university cooperating with an American university (pseudonym University ZS). Administratively, it is regarded as a subordinate institution under a state university, but it is financially independent. The College English curriculum reform in China was firstly disseminated among first rank universities, and then extended among some ordinary state universities. Reform policy documents suggest 
that only a few of the independent universities were involved in the reform program, raising the question of how the universities on the periphery of the system respond to the reform requirements. ZS University was founded in 1990 and had about 26,400 students in 2015. The specific research site was the College English Department, which provides English courses for all non-English major students in the university. The Head of the College English Department, Daniel (Pseudonym) is in charge of teaching, research and management in this department. He can be viewed as the subject of the activity system of the department. He has been teaching College English for ten years and working as the head in this department for four years at the time of data collection. He had English teaching experience in the military before he was employed in this university.

The university has a clear hierarchy of power relations among its members. The Dean of the Faculty is appointed by the Chancellor, and the Head of this department is appointed by the Dean. There are 53 full time teachers in this department teaching the course New Horizon College English. This university uses contract employment with all teachers and staff. The continued employment of the teachers, including Daniel, is evaluated by the Dean. However, Daniel's evaluation of staff plays a vital role in teacher recruitment and teacher continued employment.

In the interview with Daniel, he indicates the two main objectives for this department, which can be seen as constituting the object of the meso-level activity system. The first is to increase the CET passing ratio in this university. The second is to teach sentence structure and grammatical knowledge. In relation to the first, Daniel experienced pressure from the Chancellor to increase the ratio of students passing CET as an indicator of teaching quality in order to recruit more students and increase revenues in order to gain an edge in competition with other universities . By contrast, the second objective of teaching linguistic knowledge originated with Daniel and he required all teachers to follow this rule, even though he, somewhat contradictorily, said there were not mandatory rules for teaching.

Chinese students are not living in America or England, immersed in English use every day. Anyhow, you are living and learning English in China, (xxx). You even make mistakes in your writing. You are making mistakes indeed. Why do you make mistakes? [Because of] wrong sentence structure, wrong grammar, wrong sentence structure. 
During the interview, Daniel repeated the phrase, 'sentence structure', 26 times in relation to good teaching, suggesting that his beliefs about English learning are aligned with a structural linguistic view and a 'bottom-up' approach to reading. However, the national curriculum reform emphasizes the development of students' cultural knowledge and learning-to-learn abilities, not just basic language knowledge. This mismatch is clearly revealed in the curriculum developed by the department. To reconcile the two objectives, Daniel adopted two kinds of tools: the policy documents and employment contract.

\section{Category 1 Policy documents}

The department developed the curriculum for the College English course in 2008 (Qian \& Verhoeven, 2004) with reference to the National curriculum requirements (Document, 2010) as a guideline. At the same time, Daniel emphasized, "We have our own curriculum; We refer to (other universities' curricula) and combine with our contextual features. But these curricula are identical on major issues though with minor differences." The department's curriculum mirrors the structure and format of the national curriculum, especially the first section, which replicates the teaching objective and requirements from the national curriculum. The second section prescribes the teaching objectives and content for every unit in the textbooks. The third section “Suggestions for Teaching Approaches 教学方法建议” reveals some specific contextualized features. Table 2 compares the two curriculum documents in terms of proposed teaching models and teaching methods, the role of teaching material, and assessment.

As indicated in Table 2, the underlying pedagogical theories in these two requirements documents are very different. The national curriculum advocates a shift from teacher-centred teaching to student-centred and computer-based teaching, with the aim of cultivating students' independent learning abilities. However, the department's curriculum requirements privilege the teaching of basic language knowledge. This difference is also reflected in the requirement for teaching materials. The national curriculum advises student selection of teaching materials, but the department emphasizes the authoritative role of the textbook as both the tools and rules for teaching. The comparison suggests that the department has filtered and 
shaped the reform implementation and directed teachers' teaching approach from the requirements of the national reform.

Table 3 illustrates the comparison of the key words (both verbs and nouns) used in the CECR and the Department's curriculum. The comparison of the frequency of the discourse markers in the two curricula highlights the department's focus on the teaching of elementary linguistic knowledge and understanding, as indicated by the high frequency of the words of "basic", "knowledge", and "understanding". For example

College English must focus on building the solid foundation of basic language knowledge.

Textbooks are the important guarantee of the learning outcomes.

The assessment must focus on the basic language knowledge and the communicative ability.

In addition, in the second section of prescribed teaching objectives and content, the frequent use of the word 讲解 jiangjie 'explain' (198) indicates the teaching model advocated by the department is closely aligned to teacher-centred direct teaching. Moreover, even though the department's curriculum requirements states that testoriented teaching must be prevented, increasing the CET passing ratio is still the prime objective. Daniel made a special curriculum timetable for this course, providing an extra three weeks for practicing the CET model tests. In addition, a document, New Horizon College English Unified Classroom Teaching Content, was issued, specifying the exercises in the textbook needing to be covered:

As for the After Reading Exercises in Section A, teachers must guide students to do the exercises related to the CET test in the class, such as (1) Fill in the blanks. (2) Sentence Structure; (3) Translation; (4) Cloze. For other exercises, teachers only need to check the completion.

In the interview, Daniel also emphasize 'must':

I issue this document to every College English teacher every semester, regarding what content the teacher should cover... must, those content must be completed. They must teach sentence structure.

As can be seen from the above excerpt, the exercises required by the document focus on grammar and vocabulary, while the reformed CET focuses on reading in depth and the use of reading skills (Document, 2010). One explanation of this discrepancy is 
that the Head of the Department lacks adequate understanding of the reform requirements. In addition, in the interview, Daniel stated his military background and beliefs for discipline:

You must obey and be disciplined. I was from a military unit. Someone criticizes my style, but I believe that discipline applies to everywhere... In our Department, I emphasize teaching quality and discipline. I am strict, especially with novice teachers.

In the document title, 'unified', suggests limited space for teachers to innovate in their teaching. Moreover, the use of strong modality operators, such as "must" and "only need" reflect the authority claimed by the document and the constraints imposed on teachers' classroom practice, which resulted in a culture of compliance in the department. It is indicated that the document function as the rule for teachers' teaching practice.

\section{Category 2 Recruitment and contract---tools for managing teachers}

Daniel set teaching sentence structure as a key recruitment criterion for new teachers:

I only pay attention to [the teaching of] sentence structure in the interview with some postgraduates.

Daniel used teacher recruitment as a tool to ensure teachers complied with his requirements. Moreover, this university uses renewable, rather than ongoing, contracts to manage all staff. The renewal of each teacher's contract is based on the performance review conducted by the Head of the Department and based on student feedback. As a result, most teachers, especially young teachers, tend to be compliant with the Head's requirements in order to ensure high scores in their end of year review to keep their jobs. In addition, Daniel often observes teachers' classes to ensure that they teach according to the textbook and focus on sentence structure. These are the implicit rules governing teachers' practice in the community of this department.

Indeed, in this university, a hierarchical culture also governs both Daniel and the teachers, who all have to take orders from above. The department's curriculum requirements show little sign of change in response to the national reform agenda. Such a top-down environment, in which teachers need to comply in order to survive, suggests little, if any, scope for autonomy on the part of teachers. 


\section{Micro level - the agentive innovator}

Lynne is 45-year-old, with 17 years of English teaching experience, including seven years' experience of teaching College English. Her Master's degree research specialized in EFL reading instruction in the context of the CET reform. She has been working to improve her teaching by making use of available opportunities and resources and actively reflecting on her pedagogical practice.

Lynne set two objectives for her teaching. The "shallow level" objectives were to build up the students' vocabulary and cultural knowledge. The "deep level” objectives were to teach students global understanding and critical thinking. Lynne has formed her teaching objectives by taking into account the $\mathrm{CMoE}$ reform agenda, and its focus on global understanding, alongside the department's focus on the need for students to decode detailed lexical and grammatical information for reading comprehension. In other words, in forming these objectives, Lynne's agency has not been entirely constrained by the rules of teaching imposed by the department.

Regarding the tools Lynne used to achieve her teaching objectives, her research on EFL reading instruction in her Master's thesis provided her with a belief in a topdown, meaning-led rather than decoding-driven approach to reading pedagogy. For instance, Lynne created language artefacts to overcome the problem caused by her students' limited vocabulary:

I still focus on global understanding. I use simplified language to summarize the essence of the text according to what they can understand. Then there is less vocabulary involved. I keep reflecting on this. Firstly, I need to understand the text thoroughly, and then keep asking them questions.

Lynne has tailored her teaching according to students' knowledge and abilities by simplifying her instructional language. In addition, the adaptation of the textbook and the creation of complementary activities are additional important tools enabling Lynne to achieve her objectives. For instance, because she thought the design of the textbook for teaching reading strategies was not adequate, she looked for more suitable examples rather than giving up on this goal. In addition, in one lesson, she asked her students to evaluate and reorganize the text, thereby 'de-centring' the text and emphasising the agency of her students as meaning makers. Her continual reflection on her teaching is an effective problem-solving tool mediating her teaching practice and her professional development. 
Reflecting the assertion that language is a cultural artefact reflecting agents' intention and perception, Table 4 and 5 list the modal adverbs, verbs, and nominalization that appeared in the interview with Lynne.

The analysis reveals that Lynne has a preference for strong and median modal adverbs, reflecting her affirmative attitude towards her practice. For example, she used 要 yao 'must, need, should' and adverb 非常 feichang 'very, highly' repetitively when she talked about her beliefs about teaching,

Firstly, a talk must have a theme... (you) need to have your own idea... (the reader) should get the main idea... I told my student that this is a very necessary and very useful skill.

(A teacher) needs to let the students know critical thinking, esp, Chinese students... (we) should let them know this.

A teacher should cultivate students' comprehensive abilities.

While the use of the adverb 肯定 kending 'definitely' is a further indication of her determination make changes of the exiting curriculum.

If I could teach this course in my own way, I will definitely change this. I definitely will.

When Lynne was talking about her plan for future teaching, she has used relative marker 更 geng 'more' 24 times, expressing her desire and determination for improvement. For example,

I want to design more activities for students to be involved.

I hope they can participate more.

Lynne's use of verbs, 'want' and 'hope', also offers clues regarding her professional identity, suggesting her affective attachment to her own vision despite the constraints of her teaching situation. For instance, during the interview, Lynne's has mentioned the word 压力 yali 'stress' 11 times, indicating the difficulties of her emotional experience in the department. For example, she mentioned the stress from completing the required curriculum plan and expressed her intention to break the constraints:

I have to complete the eight units according to the curriculum plan. Otherwise my students will fail their exam.

At the same time, she expressed a positive attitude to the stress of doing research and her strong intention to maintain her professional development: 
I was elected as the Research Backbone last year. ((I)) Must do well as the backbone. I must finish two projects and three articles. There is pressure, but motivating too.

Training, definitely (I will do). I love learning and always want to learn. I want to go if there is any opportunity.

I will read more book and do more research.

At the same time, the frequency of the terms 'reflect' and 'reflection', suggest her agency in improving her teaching.

My ideas are from my person reflection and understanding. I also learn from others... after listening to other's teaching, I also reflected on my own practice about which part went well and what did went well. I reflected on how to improve.

Another important artefact is the theoretical knowledge Lynne gained from her research on the CET reform.

Since I teach this course, I will definitely keep an eye on its development. I must know (this) even before it started! My research area is the reform of College English.

Her statement reflects Lynne's sense of responsibility for her own teaching and the development of the university; having been agentive in conducting research in the college English teaching reform, she wanted to use her research to push the university to make changes accordingly. In the interview transcript, Lynne has mentioned the reform eleven times, which indicates her sense of responsibility in relation to the reform and reflecting the point that agency "entails the ability to assign relevance and significance to things and events" as well as "an awareness of the responsibility for one's own actions and of the context" (Yan, 2010, p.143).

In the university community, Lynne actively participated in many teaching and research activities, such as discussions in the weekly staff meeting and judging in the Teaching Demonstration Competition. She regarded these activities as good learning opportunities. As she said:

The university is developing. As a teacher, you must force yourself to catch up with developments. You cannot always use the old things, and refuse to adopt new things. For example, some old teachers cannot use multimedia equipment. It should not be like that. [I] will make an effort to adjust. 
Lynne's persistent effort to improve her teaching and her active involvement in various teaching and research activities at the university have won her a reputation as a capable teacher as well as promotion to the position of associate professor. Therefore, her teaching could afford to largely ignore the department's focus on test preparation: "I will mention about it [the CET], but it is not the focus of my teaching". In these ways, her higher social status and authoritative role offered her more space to develop her own teaching objectives and refine her practice, rather than being controlled by the rules set by the Head of the Department. She did not need to distort her pedagogical practice in order to make it align with the requirements of department to teach for the test and focus only on sentence structure. However, in the national reform context, Lynn did mention the disadvantaged position of her university:

$\mathrm{xxx}$ (she mentioned another set of textbooks) is designed for top-level university students and too difficult for our students. What kind of teaching material are suitable for the third-level university students? No one will design anything specific for us.

This indicates her understanding of the disadvantaged position of her university within the hierarchical power relations in the wider context.

Meanwhile, observations of Lynne in the classroom community reveal that she made efforts to engage and communicate with her students. When her students were talking about their beliefs about reading in the focus group, the frequency of terms such as "main idea", "author's purpose", and "critical reading" can be taken as the evidence that her emphasis on global understanding and her modelling of critical reading through her interactions with her students in the classroom has been internalized in her students' beliefs. This further affirms Lynne's agency in making the classroom community more supportive of her teaching. For example, students in the focus group talked about their beliefs about reading:

I think it is necessary to understand the overall structure, and then from the content to understand the author's ideas and feelings. Our teacher instilled this idea in us, so I think so.

I have learned from Lynn's class that reading also means to appreciate the beautiful language.

Our teacher (Lynn) always evaluates the readings in the textbook. I don't think teaching should follow the textbook rigidly, but should be critical. 
On the other hand, the dominance of the Initiation-Response-Evaluation (IRE) pattern of teacher-student interaction has also constrained students' participation in her classroom. One student in the focus group stated:

Very often, she uses eye contact to encourage us to speak, but most students lower their heads, some even are sleeping and a few stand up (to answer her questions). Sometimes, I do not know how to answer, so I just lower my head. Lynne attempted to solve this problem by reframing her questions, but this was not very effective, because, no matter how she reframed her questions, the IRE pattern remained dominant and her students were still expected to give response rather than as independent thinkers and learners. This contradiction could be resolved if the discourse pattern could be changed and students were given more responsibility in their learning.

Overall, Lynne's research on the college English teaching reform strengthened her knowledge of teaching and helped her to establish objectives consistent with the reform requirement, while allowing her to at least partially ignore the department's teaching rules. Lynn consistently exhibited agency in reflecting on her teaching, designing various teaching activities, and persuading the students to accept her beliefs in order to achieve her teaching goals. Overall, she not only internalized the theory of teaching advocated by the $\mathrm{CMoE}$ reform, she reworked this knowledge through her active tool creation and also established another, 'personal' teaching objective in the form of critical reading, based on her life experience. In these ways, notwithstanding the constraints of the prescriptive rules for teaching and the hierarchical departmental climate in the department - a climate exacerbated by the top-down nature of the national culture of reform - and despite her limited success in overcoming the IRF interactive pattern in her interactions with her students, Lynne was nonetheless able to carve out a certain space for agentive teaching. Specifically, by formulating new teaching objectives, enacting transformation in her classroom, and by continually learning from her professional experiences, Lynne embodied possibilities for teacher agency and autonomy.

\section{Discussion and conclusion}

As noted in the introduction, large-scale educational reform is a complicated process involving interaction between individuals, institutions and national-state policy. In an 
attempt to capture this complexity our study has employed third generation activity theory. Figure 2 below reveals the interaction between the three-level activity systems of the curriculum reform community.

The analysis suggests that the control-compliance model functioned as the rule for the curriculum implementation in both the activity systems of the $\mathrm{CMoE}$ and the Department. The CMoE Curriculum Requirement employed imperative sentences, some strong modality operators and terms from managerial discourse, highlighting its authoritative position and placing the universities in a compliant role. These reinforce the culture of conformity in relation to the implementation of the reform, which is in accordance with Li (2011)'s findings, in which the use of research projects and inservice training as tools to build up teachers' capacity was only accessible to top universities. This resulted in not only gaps between the theories of teaching espoused in the national reform and those operating in local institutions but also in educational inequity.

At the meso-level, the university where the current study was conducted was marginalized and consequently the Head of the Department, Daniel, lacked much by way of knowledge and understanding about the purpose and content of the national reform agenda. As a result, the department's curriculum merely borrowed occasional sentences from the national curriculum documentation but its teaching objectives and teaching method requirements remained based on Daniel's beliefs about English teaching and learning. The incongruence between the underlying theories of teaching and learning in these two activity systems indicates the unequal opportunity in access to resources, which puts some institutions and their teachers in a disadvantaged position and results in a combination of superficial compliance alongside resistance to the reform at the institutional level. In addition, both Daniel and Lynne acknowledged that their university was placed at the bottom level with inadequate support and resources, suggesting that they have accepted that reality that as a lower level institution, they don't have much voice in the process of education policy making and reform (Li, 2011, p.189). At the same time, the frequent use of high modal operators in the department's documents, as well as in Daniel's interview texts, indicates that Daniel, as the Head of the department, is using language to create his authoritative role and impose his pedagogical beliefs on the teachers. It can be concluded that the 'policy making elites' (Li, 2011, p.189) at each level of this hierarchical structure, 
including the $\mathrm{CMoE}$ at the top level and Daniel at the department level, have used language to exert power and promote conformity.

Within a context such as this, it is hard to expect teachers to be active agents and to proactively make changes in response to reform. However, Lynne demonstrated considerable agency in enacting transformation within a constraining context. Lynne's agency in decision-making and her assumption of responsibility for her professional development, reflected in her frequent use of strong modality adverbs, was evident in the differences between her priorities and those of her department. Factors that may have contributed to her professional agency include her ongoing research, her practical experience, her reflection, and her engagement with the community. Specifically, Lynne acquired theoretical knowledge about pedagogy from her research into college English teaching and she was able to connect this knowledge with her extensive practical experience through her ongoing reflection on teaching (see Hong \& Youngs, 2014). Moreover, her active participation in university's professional learning activities further empowered her professional agency despite her controlling departmental culture, highlighting how agency is a social and relational process mediated by the sociocultural context (Cole \& Engeström, 1993; Kim, 2011). These insights were afforded by the use of an activity theory framework combined with critical discourse analysis in analysing the interaction between different stakeholders within the reform community. This analytical framework was helpful in identifying is the existence of mutual goals, or of tension and slippage, between the different levels of reform implementation, whilst also highlighting the play of power relationships between these systems, in the shape of the hierarchical relations between the CMoE, the institute and the teacher - relations more clearly illuminated by the employment of tools from CDA.

While recognising that, as a single case study, the generalizability of the findings from this study is limited, this paper nonetheless offers insights into the possibilities for teacher development in contexts dominated by educational reform. Specifically, Lynne's case suggests that teacher agency can be enhanced through capacity building activities, such as engaging in research and reflecting on teaching, even in a highly restrictive institutional context. Indeed, Lynne's experience suggests ways in which teachers can comply with the official requirements of reform whilst also continuing to innovate in relation to their professional practice, thus bringing about further 
unanticipated and potentially subversive and resistant practitioner-led reform - in other words, reform that is not initiated from above but led by changes from below. 


\section{References}

$\mathrm{Au}, \mathrm{W}$. (2011). Teaching under the new Taylorism: High-stakes testing and the standardization of the 21st century curriculum. Journal of Curriculum Studies, 43(1), $25-45$.

Ball, S. J. (2012). Global education Inc.: New policy networks and the neo-liberal imaginary. New York: Routledge.

Ball, S. J., Maguire, M., \& Braun, A. (2012). How schools do policy: Policy enactments in secondary schools. London: Routledge.

Blackler, F. \& McDonald, S. (2000). Power, mastery and organizational learning. Journal of Management Studies, 37, 833-852.

Cheng, M. (2016). The power of persuasion: Modality and issue framing in the 2012 Taiwan Presidential Debates. Discourse \& Society, 27(2), 172-194.

CMoE. (2002). Higher education quality and reform program. Retrieved from http://www.zlgc.edu.cn/Detail.espx?Id/1140.

CMoE. (2003). Guanyu kaizhan daxue yingyu jiaoxue gaige shidian gongzuo de tongzhi [The notice of launching the pilot projects of the College English curriculum reform]. (Report No. 226). Retrieved from http://www.moe.edu.cn/publicfiles/business/htmlfiles/moe/s3857/201007/933 26.html.

CMoE. (2004a). Daxue yingyu kecheng jiaoxue yaoqiu (shixing) [College English curriculum requirements (trial)]. (Report No. 1). Retrieved from http://www.moe.edu.cn/publicfiles/business/htmlfiles/moe/s3857/201011/110 837.html.

CMoE. (2004b). Guanyu shishi daxue yingyu jiaoxue gaige shidian gongzuo de tongzhi [The notice of implementing the pilot projects of the College English curriculum reform]. (Report No. 21). Retrieved from http://www.moe.edu.cn/publicfiles/business/htmlfiles/moe/s3857/201007/933 42.html.

CMoE. (2007). Daxue yingyu kecheng jiaoxue yaoqiu [College English curriculum requirements]. (Report No. 3). Retrieved from http://www.moe.edu.cn/edoas/website18/info34295.htm.

CMoE. (2017). Quanguo gaodeng xuexiao mingdan [The list of tertiary institute in the country]. Retrieved from 
http://www.moe.gov.cn/srcsite/A03/moe_634/201706/t20170614_306900.htm 1

Cole, M., \& Engeström, Y. (1993). A cultural-historical approach to distributed cognition. In G. Salomon (Ed.), Distributed cognitions: Psychological and educational considerations (pp. 1-46). New York: Cambridge University Press.

Day, C., \& Gu, Q. (2013). Resilient teachers, resilient schools. London: Routledge.

Document, Z. S. (2010). Daxue yingyu jingpin kechange wangzhan --- Kecheng dagang [College English top quality course --- New Horizon College English curriculum]. Retrieved from http://sfl.sias.edu.cn/course/contents/652/1399.html

Document, Z. S. (2015). About SIAS. Retrieved from http://en.sias.edu.cn/AboutSias/2459/9789.html

Duff, P. (1996). Different languages, different practices: Socialization of discourse competence in dual-language school classrooms in Hungary. In K. Bailey \& D. Nunan (Eds.), Voices from the language classroom: Qualitative research in second language education (pp. 407-433). New York: Cambridge University Press.

Engeström, Y. (1987). Learning by expanding: An activity-theoretical approach to developmental research. Helsinki: Orienta-Konsultit.

Engeström, Y. (2001). Expansive learning at work: toward an activity theoretical reconceptualization. Journal of education and work, 14(1), 133-156.

Engeström, Y. (2009). The future of activity theory: A rough draft. In A. Sannino, H. Daniels, \& K. D. Gutiérrez (Eds.), Learning and expanding with activity theory (pp. 303-328). Cambridge, UK: Cambridge University Press.

Engeström, Y., \& Miettinen, R. (1999). Introduction. In Y. Engeström, R. Miettinen, $\&$ R. Punamaki (Eds.), Perspectives on activity theory (pp. 1-16). Cambridge: Cambridge University Press

Fairclough, N. (2001). Language and power (2nd ed.). Harlow: Longman.

Fairclough, N. (2003). Analyzing discourse: textual analysis for social research. London ; New York: Routledge.

Fowler, R. (1985). Power. In T. A. van Dijk (ed.), Handbook of Discourse Analysis, Vol. 4. (pp.61-82). London: Academic Press, Inc. 
Gu, Q. (2013). The work, lives and professional development of teachers in China. Asia-Pacific Journal of Teacher Education, 41(3), 235-238.

Halliday, M.A.K. (1994). An introduction to functional grammar (2nd ed.). London: Edward Arnold.

Hargreaves, A. (2003). Teaching in the knowledge society: Education in the age of insecurity. Maidenhead: Open University Press.

Hong, W.-P., \& Youngs, P. (2014). Why are teachers afraid of curricular autonomy? Contradictory effects of the new national curriculum in South Korea. Asia Pacific Journal of Education, 1-14.

Johnson, K. E., \& Golombek, P. R. (2011). A sociocultural theoretical perspective on teacher professional development. In K. E. Johnson \& P. R. Golombek (Eds.), Research on second language teacher education: A sociocultural perspective on professional development (pp. 1-12). New York: Routledge.

Kim, E.-J. (2011). Ten years of CLT curricular reform efforts in South Korea: An activity theory analysis of a teacher's experience. In K. E. Johnson \& P. R. Golombek (Eds.), Research on second language teacher education: A sociocultural perspective on professional development (pp. 225-238). New York: Routledge.

Lasky, S. (2005). A sociocultural approach to understanding teacher identity, agency and professional vulnerability in a context of secondary school reform. Teaching and Teacher Education, 21(8), 899-916.

Leont'ev, A. N. (1981). Problems in the development of the mind. Moscow, Russia: Progress.

Li, M. (2011). Shaping socialist ideology through language education policy for primary schools in the PRC. Current Issues in Language Planning, 12(2), 185-204.

Lillian, D. L. (2008). Modality, persuasion and manipulation in Canadian conservative discourse. Critical Approaches to Discourse Analysis across Disciplines, 2(1), 1-16.

Liu, S., \& Rosa, M. J. (2008). Quality assessment of undergraduate education in China: a policy analysis. Higher Education Management and Policy, 20(3), 79-96. 
Lo, L. N. K., Lai, M., \& Wang, L. (2013). The impact of reform policies on teachers' work and professionalism in the Chinese Mainland. Asia-Pacific Journal of Teacher Education, 41(3), 239-252.

Qian, X., \& Verhoeven, J. C. (2004). From centralization to decentralization in Chinese higher education. education policy analysis archives, 12(67), 1-26.

Stoller, A. (2015). Taylorism and the logic of learning outcomes. Journal of Curriculum Studies, 47(3), 317-333.

van Huizen, P., van Oers, B., \& Wubbels, T. (2005). A Vygotskian perspective on teacher education. Journal of curriculum studies, 37(3), 267-290.

Wertsch, J. V., Tulviste, P., \& Hagstrom, F. (1993). A sociocultural approach to agency. In E. A. Forman, N. Minick, \& C. A. Stone (Eds.), Contexts for learning: Sociocultural dynamics in children's development (Vol. 23, pp. 336356). Oxford: Oxford University Press.

Wette, R., \& Barkhuizen, G. (2009). Teaching the book and educating the person: Challenges for university English language teachers in China. Asia Pacific Journal of Education, 29(2), 195-212.

Yan, J. (2010). The national College English Test Committee. In L.Cheng \& A.Curtis (Eds.), English language assessment and the Chinese learner (pp. 44-59). New York: Routledge.

Yin, H. (2012). Adaptation and validation of the teacher emotional labour strategy scale in China. Educational Psychology, 32(4), 451-465.

Zhong, Q. (2006). Curriculum reform in China: Challenges and reflections. Frontiers of Education in China, 1(3), 370-382. 
Tables with captions

\begin{tabular}{|l|l|}
\hline Key verbs and modal verbs & CECR \\
\hline 评估 Assess & 31 \\
\hline 懂 Know & 35 \\
\hline 理解 understand & 28 \\
\hline 熟悉 familiarize & 12 \\
\hline 管理 manage & 12 \\
\hline 学习 learn & 56 \\
\hline 要求 require/requirement & 58 \\
\hline 能力/ 能 ability/able & 43 \\
\hline 需要 Need(s) & 32 \\
\hline 应/应该 Should & 96 \\
\hline
\end{tabular}

Table 1: Occurrences of key verbs and modal verbs in CECR. 


\begin{tabular}{|c|c|c|}
\hline & CECR & Dept. curriculum \\
\hline $\begin{array}{l}\text { Requirements for } \\
\text { teaching } \\
\text { models/methods }\end{array}$ & $\begin{array}{l}\text { "For teaching methods, the reform } \\
\text { consists of changes in teaching } \\
\text { philosophy and practice, and in a } \\
\text { shift from a teacher-entered pattern, } \\
\text { in which knowledge of the language } \\
\text { and skills are imparted by the teacher } \\
\text { in class only, to a student-centred } \\
\text { pattern, in which the ability to use the } \\
\text { language and the ability to learn } \\
\text { independently are cultivated in } \\
\text { addition to language knowledge and } \\
\text { skills, and also to lifelong education." } \\
\text { (CMoE, 2007) }\end{array}$ & $\begin{array}{l}\text { "To build language basics, including } \\
\text { language knowledge and the ability to } \\
\text { use English. The correct pronunciation } \\
\text { and intonation, solid grammar, certain } \\
\text { amount of vocabulary and the ability to } \\
\text { use, vocabulary are useful to improve } \\
\text { the ability to use language. In addition, } \\
\text { improve student's cultural awareness." } \\
\text { (CMoE, 2007) }\end{array}$ \\
\hline $\begin{array}{l}\text { Teaching } \\
\text { materials }\end{array}$ & $\begin{array}{l}\text { "The new model should enable } \\
\text { students to select materials and } \\
\text { methods suited to their individual } \\
\text { needs." } \\
\text { "Colleges and universities should } \\
\text { adopt good teaching software and } \\
\text { encourage teachers to make effective } \\
\text { use of web multimedia and other } \\
\text { teaching resources." }\end{array}$ & $\begin{array}{l}\text { "In order to build a solid language } \\
\text { foundation, to develop language } \\
\text { proficiency, and to improve students' } \\
\text { literacy, textbooks should provide the } \\
\text { best language samples, and systematic } \\
\text { language activities for the classroom } \\
\text { teaching." (Document, 2010) }\end{array}$ \\
\hline $\begin{array}{l}\text { Testing and } \\
\text { evaluation }\end{array}$ & $\begin{array}{l}\text { Suggest both formative and } \\
\text { summative tests. }\end{array}$ & $\begin{array}{l}\text { "Tests should focus on language } \\
\text { knowledge and language use ability } \\
\text { with certain amount of subjective } \\
\text { questions. Test-oriented teaching must } \\
\text { be prevented." (Document, 2010) }\end{array}$ \\
\hline
\end{tabular}

Table 2: The comparison of the differences between the national curriculum requirements and department's curriculum requirements. 


\begin{tabular}{|l|l|l|}
\hline $\begin{array}{l}\text { Key Verbs and } \\
\text { nominalisation }\end{array}$ & CECR & Dept. curriculum \\
\hline 评估 Assess & 31 & 0 \\
\hline 理解 understand(ing) & 28 & 148 \\
\hline 学习 learn & 56 & 19 \\
\hline 要求 require & 58 & 59 \\
\hline 能力/ 能 ability/able & 43 & 144 \\
\hline 解释 explain & 0 & 198 \\
\hline 知识 Knowledge & 0 & 148 \\
\hline 基础 basics & 0 & 90 \\
\hline
\end{tabular}

Table 3: Occurrences of verbs and nouns in CECR and the Department's curriculum.

\begin{tabular}{|l|l|}
\hline Use of modal adverbs & $\begin{array}{l}\text { Frequency of the words in Lynne's } \\
\text { interview }\end{array}$ \\
\hline 应该 should & 14 \\
\hline 必须 must & 18 \\
\hline 可能 might & 20 \\
\hline 会 will & 61 \\
\hline 肯定 definitely & 34 \\
\hline
\end{tabular}

Table 4 The frequency of modal adverbs used in Lynne's interview 


\begin{tabular}{|l|l|}
\hline Verbs and nominalisation & $\begin{array}{l}\text { Frequency of the words in Lynne's } \\
\text { interview }\end{array}$ \\
\hline 改革 reform & 11 \\
\hline 压力 pressure/stress & 11 \\
\hline 参与 participate & 11 \\
\hline 帮助 help & 12 \\
\hline 思考 reflect & 12 \\
\hline 设计 design & 14 \\
\hline 考试 exam & 15 \\
\hline
\end{tabular}

Table 5 The frequency of key verbs and nominalisation used in Lynne's interview 


\section{Figure captions}

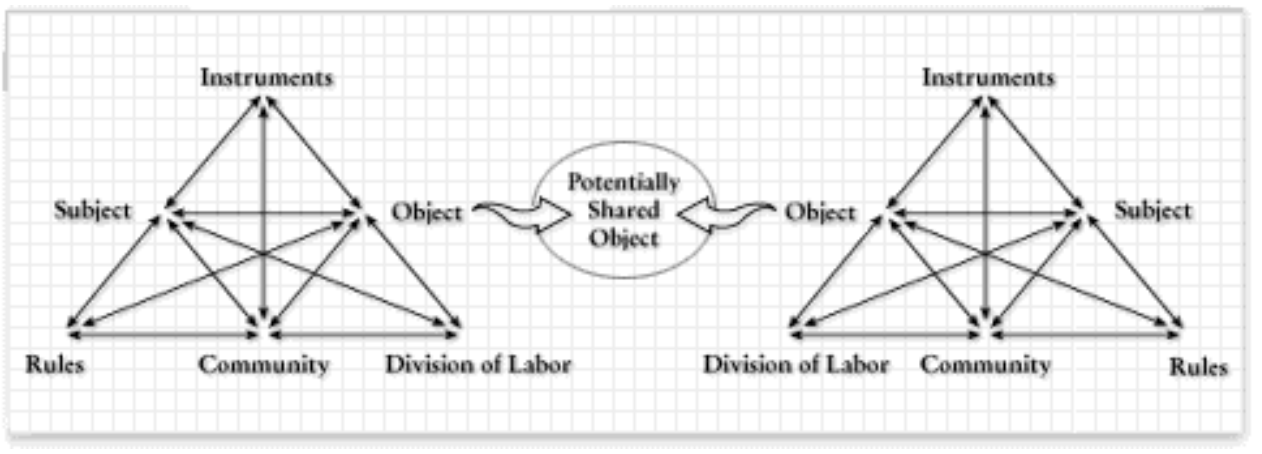

Figure 1. Minimal model for third generation activity theory (Wertsch, Tulviste, \& Hagstrom, 1993)

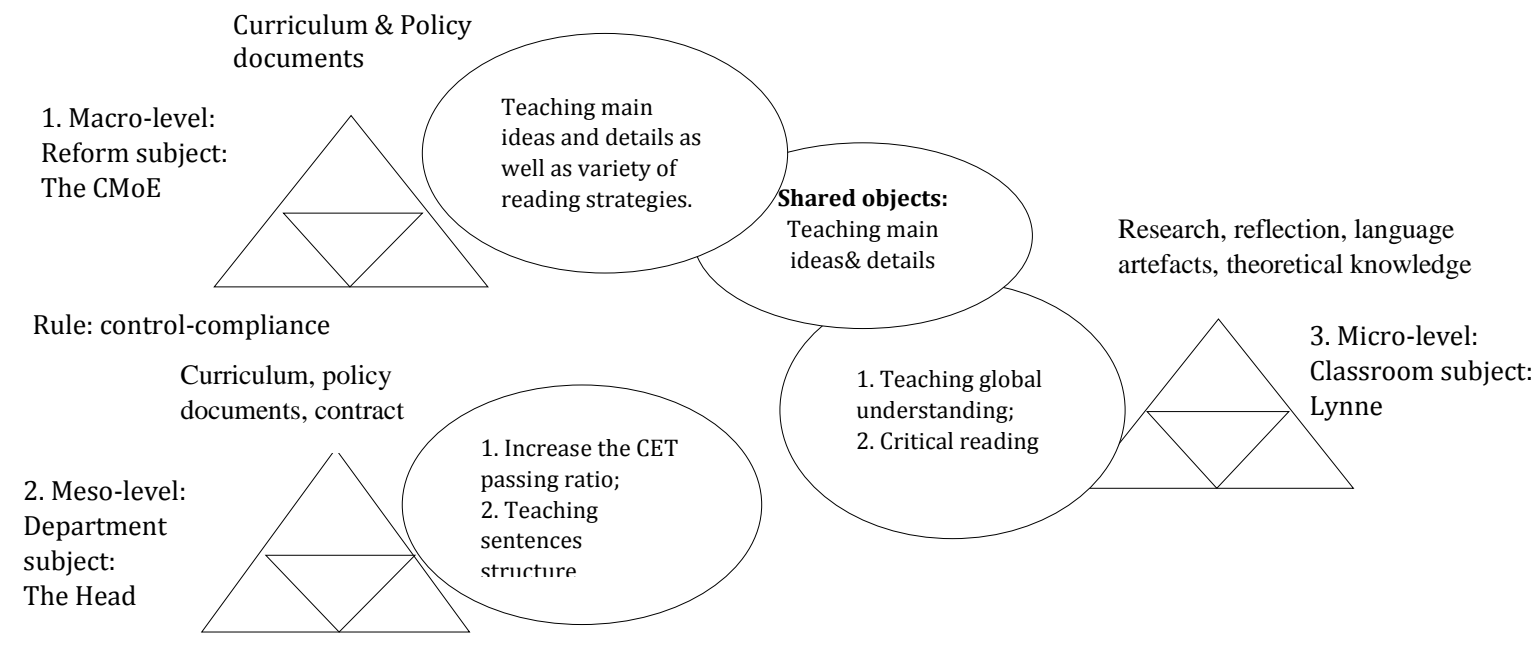

Rule:_control-compliance

Figure 2. The interaction of the three activity systems. 